\title{
Cyanotoxins in Serbia and Water Treatment Procedures for their Elimination
}

\author{
Tokodi NadaA, Drobac DamjanaA, Svirčev ZoricaA, Lazić Dragana ${ }^{\mathrm{B}}$ \\ Received: June 2012 | Revised: July 2012 | Accepted: July 2012
}

\begin{abstract}
Cyanotoxins are secondary metabolites produced by cyanobacteria, mainly as a result of eutrofication and water quality deterioration. The most common cyanotoxins are cyclic peptide hepatotoxins called microcystins. Cyanotoxins represent a potential health risk for humans when occuring in freshwaters used for drinking water supply, recreation and irrigation. In Serbia there is a problem with cyanobacterial blooms and production of cyanotoxins in most of the surface freshwaters. In order to restore water quality, various techniques and methods in water treatment procedures must be employed. These procedures include technologies like coagulation/floculation, flotation, filtration, activated carbon adsorption, UV photolysis, ozonization and oxidation processes. This review focuses on cyanotoxins, their occurrence in Serbia, as well as ways of their removal from the water.
\end{abstract}

Key words: Cyanotoxins, Microcystin-LR (MC-LR), Drinking water, Water treatment

\begin{abstract}
Abbreviations: MC, microcystin; MC-LR, Microcystin-LR; PLC, primary liver cancer; DAF, dissolved air flotation; MF, microfiltration; UF, ultrafiltration; NF, nanofiltration; RO, reverse osmosis; PAC, powdered activated carbon; GAC, granular activated carbon; WHO, World Health Organisation
\end{abstract}

\section{Introduction}

Water is a fragile resource. It is renewable through the natural cycle, however, human activities have disrupted this fine process, mostly due to the lack of environmental consciousness and knowledge of how to establish sustainable systems of water resources management. Accelerated eutrophication of water ecosystems, as a direct consequence of the rapid increase of human population, urbanization and modern agriculture practice, has apparently intensified the occurence of the toxic cyanobacterial blooms as well (Svirčev, et al., 2008). It is found that $50-75 \%$ of the cyanobacterial blooms were toxic (WHO, 2003). Microcystis aeruginosa is one, of many, cyanobacterial species that can form harmful algal blooms in freshwater water bodies worldwide. The alarming rate of increase in harmful al- gal blooms signals the need for an evaluation of surface water management and restoration policy, and identification of methods for reversing eutrophication trend, if we are to have a sustainable supply of usable freshwater (Hudnell, 2010a,b).

\section{Cyanotoxins}

Cyanobacteria is a group of prokaryotes whose history goes back 2.7 billion years. The majority of cyanobacteria are aerobic photo-autotrophs, and their life processes require only oxygen, light and inorganic substances. The cyanobacteria in eutrophic waters and under specific environmental conditions can grow excessively, producing blooms. Cyanobacteria distribution is ubiquitous and nowadays their overgrowth has become an

\footnotetext{
A Department of Biology and Ecology, Faculty of Science, University of Novi Sad, Trg Dositeja Obradovića 3, 21000 Novi Sad, Serbia

B Elementary School "Svetozar Toza Marković", Janka Čmelika 89, 21000 Novi Sad, Serbia

* Corresponding author: Tokodi Nada; e-mail: biometatandem@gmail.com
} 
important water quality problem in many countries due to the production of toxins that are released to the water. Cyanotoxins are a diverse group of bioactive substances which are produced by cyanobacteria.

Depending on which structure of the human body is affected, cyanotoxins are classified as: hepatotoxins (microcystins, nodularin, cylindrospermopsin), neurotoxins, cytotoxins (aplysiatoxin, debromoaplysiatoxin, lingbyatoxin, lipopolysaharide endotoxin) and skin and gastrointestinal irritants (Kaebernick, Neilan, 2001; Briand, et al., 2003; Falconer, 2008).

Cyanotoxins can be enclosed in the cell walls, exist intracellularly in the cytoplasm, or be released by excretion and become extracellular cyanotoxins. Release of toxins occurs during the cell life, but mostly after cell death through passive flow out of the cellular content (Chorus, 2001; Griffiths, Saker, 2003).

The most commonly detected cyanotoxins are the cyclic heptapeptide hepatotoxins called microcystins (MCs), of which over 80 structural variants are currently known (Dietrich, Hoeger, 2005; Babica, et al., 2006), and the most common are MC-LR, MC-RR, $\mathrm{MC}-\mathrm{YR}$, and MC-LA variants (WHO, 2004). MCs are extremely stable and resistant to common chemical breakdown such as hydrolysis or oxidation under conditions found in most natural water bodies. These cyanotoxins can initiate cancer and promote tumor formation in the liver of humans and wildlife (Žegura, et al., 2003; IARC, 2006; Ibelings, Havens, 2008).

The health threats caused by cyanotoxins, especially MCs, have led the World Health Organization (WHO) to establish a provisional guideline value for MC-LR of $1 \mu \mathrm{g} / \mathrm{L}$ in drinking water (WHO, 1998). This led to efforts by water suppliers to develop effective cyanotoxin removal treatments and management approaches for safe drinking water (Hitzfeld, et al., 200o).

\section{Situation in Serbia}

During a brief survey (summer 2005-spring 2006) of 16 aquatic ecosystems in Vojvodina region regarding bloom events of potentially toxic and toxic cyanobacteria species, almost $60 \%$ of investigated water bodies were found in blooming. The most dominant detected bloom forming cyanobacteria species were all belonging to potentially toxin or toxin production species, MC being the most frequently produced toxin (Simeunović, et al., 2005). Investigations by Svirčev and associates (2006) showed that the water quality in Ćelije, Bovan, Grliška, Gruža, Bukulja, Garaši, Borkovac, and Pavlovci reservoirs, and 20 aquatic ecosystems in Vojvodina were in such stage that accelerated eutrophication has been confirmed. One of the key symptom of eutrophication are cyanobacterial blooms.
As far back as 1980, large number of water ecosystems in Serbia was found in blooming (Fig.1A). Among 83 water ecosystems examined, 58 were found in blooming condition during last 2.5 decades. All natural lakes, accumulations, rivers and chanals in Vojvodina Province (agricultural part) proved to be sites with frequent cyanobacterial proliferation (Svirčev, et al., 2007). Dominant blooming cyanobacterial taxa belonged to Microcystis, Aphanizomenon, Anabaena and Oscillatoria (Planktothrix) genera, all of which are well known toxin producers. The part of Central Serbia has been found to be very risky for surface reservoirs water supply since more than 20 reservoirs serve as drinking water suppliers, nine of which were detected in severe and prolonged cyanobacterial blooming (Fig.1B) (Svirčev, et al., 2007).

Epidemiological studies have suggested that there is connection between primary liver cancer (PLC) and MCs, as one of risk factor for high incidence rate of PLC in Serbia (Juković, et al., 2008). Drobac and associates (2011) could not conclude that the main risk factors, liver cirrhosis, chronic hepatitis B virus and chronic hepatitis $\mathrm{C}$ virus, represent the main and only cause of PLC. One of the risk factors of PLC, and therefore the reasons for its uneven geographical distribution, can be presence of hepatotoxins in drinking water. Based on existing data, it was found that the high incidence of PLC correlates with the appearance of water blooms and the presence of MCs (Svirčev, et al., 2009).

Detected rapid eutrophication and water quality deterioration in investigated freshwater ecosystems evidently demand rapid implementation of revitalization measures (Svirčev et al., 2008). Environmental situation deserves immediate attention by authorities in charge for preserving the environmental quality. Mass presence of the potentially toxic species represents latent and real threat to human and animal health, but also an important indicator of the rapid water quality deterioration which could represent challengeable obstacle for the future development of the region (Simeunović, et al., 2005). Therefore, it is recommended that necessary measures for preservation of local environment, particulary water quality, should be established in Serbia.

\section{Water treatment procedures for the removal of cyanotoxins}

Since water is essential for life, providing the human population with safe drinking water is one of the most important issues in public health.

Cyanotoxins cause serious problems, and the first step for cyanotoxin control is the prevention of eutrophication process and reducing cyanobacterial blooms in surface freshwaters used for water supply. The next preference for 


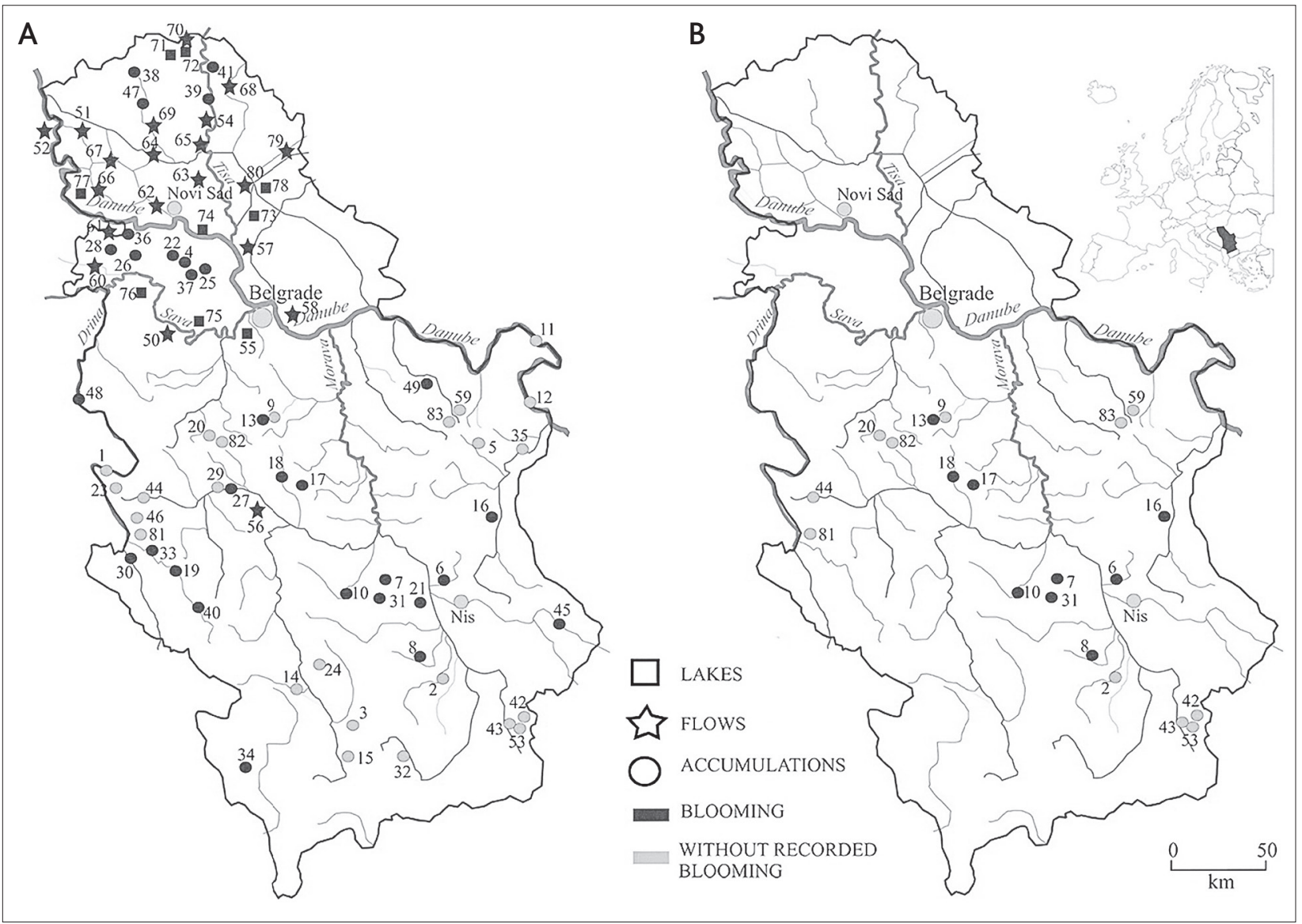

Figure 1. (A) Freshwater ecosystems monitored in the past 25 years in Serbia with detected blooming events; (B) Drinking water supply reservoirs in Central Serbia with blooming ones marked by dark grey dots (Svirčev, et al., 2007).

Legend: 1.Bajina Bašta, 2.Barje, 3.Batlava, 4.Borkovac, 5.Borsko jezero, 6.Bovan, 7.Bresnica, 8.Brestovac, 9.Bukulja, 10.Ćelije, 11.Đerdap I, 12.Đerdap II, 13. Garaši, 14.Gazivode, 15.Gračanka, 16.Grlište, 17.Grošnica, 18.Gruža, 19.Kokin Brod, 20.Kamenica, 21.Krajkovac, 22.Kudoš, 23.Lazić, 24.Lisina, 25.Ljukovo, 26.Međeš, 27.Međuvršje, 28.Moharač, 29.Ovčar Banja, 30.Potpeć, 31.Pridvorica, 32.Prilepnica, 33.Radojina, 34.Radonji, 35.Sokolovica, 36.Sot, 37.Šelovrenac, 38.Tavankut, 39.Tisa, 40.Uvac, 41.Tisa-Novi Kneževac, 42.Vlasina, 43.Vrla 2, 44.Vrutci, 45.Zavoj, 46.Zlatibor, 47.Zobnatica, 48.Zvornik, 49.Pek-Blagojev kamen, 50.Sava Litije-Ostružnica, 51.Kanal Odžaci-Sombor, 52.Dunav-Apatin, 53.Vrla 1, 54.Mrtva TisaMol, 55.Rakina bara, 56.Zapadna Morava-Čačak, 57.Opovački Dunavac, 58.Ponjavica, 59.Veliki Zaton, 6o.Bosut, 61.Studva, 62.DTD-Novi Sad, 63.Jegrička, 64.DTD-Vrbas, 65.DTD-Bačko Gradište, 66.DTD-Bač, 67.DTD-Srpski Miletić, 68.Zlatica, 69. Krivaja, 70.Kereš, 71.Palić, 72.Ludoš, 73.Carska bara, 74.Koviljski rit, 75.Obedska bara, 76.Zasavica, 77.Provala, 78.Ečka, 79.Stari Begej-Srpski Itebej, 80.Tamiš-Botoš, 81.Ribnica, 82.Divčibare, 83.Pustinjac

cyanotoxin control in water is water body menagement which includes different techniques and treatments in order to reduce cyanobacterial growth and cyanotoxins (Mouchet, Bonnelye, 1998; Chorus, Bartram, 1999).

Conventional surface drinking water treatments may need to be optimised for cyanotoxin removal, depending on the form of the toxin to be removed (intraor extracellular), the background water matrix, and possible dissolved toxin release during the treatment process (Falconer, 2005). Chemical and physical properties of the cyanotoxins such as the hydrophobicity, hydrophilicity, molecular size, and functional groups affect the efficiency of treatment of extracellular cyanotoxins (Westrick, et al., 2010).
There are several mechanisms of soluble and particulate contaminant removal used in the treatment of drinking water:

- Physical/biological processes

1. Coagulation/Sedimentation

2. Flotation

3. Filtration: rapid rate, slow sand, membrane

4. Adsorption: activated carbon

5. Probiotic bacteria

\section{- Chemical processes}

1. Oxidation: chlorine, chloramines, chlorine dioxide, potassium permanganate, ozone

2. Advanced Oxidation: Fenton process, UV photolysis 
These processes may work singularly, or in conjunction with each other to accomplish contaminant reduction, which could be done through the pathways of removal, degradation, and/or a reduction or inactivation of toxicity of the target compound.

\section{Coagulation/flocculation}

Coagulation or flocculation involves the aggregation of smaller particles into larger particles using chemicals such as ferric chloride or aluminum sulfate. $\mathrm{Pi}$ etsch and associates (2002) showed an increase in dissolved MC-LR concentration after flocculation, therefore, coagulant doses, cell counts and other parameters indicating potential toxin release should be monitored under potential bloom conditions. The highest removal ratio of $M$. aeruginosa was $93.5 \%$ by the sonication-coagulation method. Experiments with reservoir water showed that this method could be successfully applied to natural water containing multiple species of algae (Zhang, 2009). Although most investigations have mainly involved MCs, significant removal of dissolved fractions has not been demonstrated for other cyanotoxin variants, such as saxitoxins and cylindrospermopsin (Hoeger, et al., 2004).

\section{Dissolved air flotation (DAF)}

Dissolved air flotation is used mainly to remove suspended and colloidal solids by flotation (rising) by decreasing their apparent density (Wang, et.al., 2005). A gas (often air) is introduced near the bottom of the water column and the resulting bubbles attach to particles as they move upward to the surface. Flotation is effective for cyanobacterial cell removal, since bubbles are used to lift particles, and mechanical mixing is not used, cell damage and subsequent toxin release is avoided.

Although cyanobacterial cell removal by DAF has been documented, its removal efficiency for toxins is questionable (Yoo, et al., 1995; Hrudey, et al., 1999). The results by Ribau Teixeira and Rosa (2006a) showed no significant removal of several dissolved MC variants (LR, LY, LW, and LF) in air flotation experiments. Therefore, flotation may be a good choice for toxin removal if the toxin is still contained within the cell, but should most likely be used in combination with other processes if dissolved toxin removal is required. Coagulation/flocculation/DAF+nanofiltration guaranteed a full removal of the cyanobacterial biomass and the associated MCs variants (MC-LR, MC-LY, MC-LW and MC-LF) in drinking water (Ribau Teixeira, Rosa, 2006a).

\section{Rapid filtration and slow sand filtration}

Biologically active filtration, both slow and rapid filtration, have been reported to remove or to inactivate MCs in drinking water (Lahti, et al., 2001; Bourne, et al., 2006). Some studies have shown that direct rapid filtration was not effective in removing cyanobacterial cells, while slow sand filters can remove $99 \%$ of the cells (Lepisto, et al., 1994; Mouchet, Bonnelye, 1998; Grutzmacher, et al., 2002).

Rapid filtration is a method usually used after a coagulation step in conventional water treatment and requires regular backwashing of the filters. If this process is performed inadequately, lysis of cyanobacterial cells and release of cyanotoxins into the water can occure (Chorus, Bartram, 1999).

Slow sand filtration possibly develops a biofilm on the top of the filter, due to its lower loading rate, resulting in biodegradation of MCs (Svrcek, Smith, 2004). Grutzmacher and associates (2002) conducted two experiments to study the removal of MCs by biologically active slow sand filtration, and the overall elimination rates ranged from $43 \%$ to $99 \%$, with values below $85 \%$ occurring in late autumn at low temperatures. Slow sand filtration is potentially very useful if combined with other water treatments (Chorus, Bartram, 1999).

\section{Membrane processes - microfiltration (MF), ultrafiltration (UF), nanofiltration (NF) and reverse osmosis (RO)}

Membrane filtration is a physical process that separates contaminants by size and charge depending on the physical/chemical characteristics of the membrane. An important point when considering filtration is the lysis of cells. Membrane filtration is a pressure driven process which uses size exclusion, charge repulsion, adsorption and/or diffusion processes for removal mechanisms. Generally, there are four processes that are considered feasible and more commonly used for membrane treatment in drinking water applications: microfiltration, ultrafiltration, nanofiltration and reverse osmosis.

Two types of low-pressure membrane filtration, MF and UF, have been shown to be effective in removal of intact cyanobacterial cells (Gijsbertsen-Abrahamse, et al., 2006). These membranes removed more than $98 \%$ of the cells, but are unable to reject dissolved toxins (Ribau Teixeira, Rosa, 2006b). Lee and Walker (2006) evaluated two types of UF membranes and their experiments showed that it is not a reliable treatment barrier for cyanotoxins.

$\mathrm{RO}$ and NF membranes could remove dissolved MCs, but removal depends on the membrane pore size and water quality (Gijsbertsen-Abrahamse, et al., 2006). Several variants of MC (RR, LR, YR, and LA) were used in the tests and, in most cases, toxin was removed to below detection limits by the membrane. According to Ribau Teixeira and Rosa (2006b), NF is able to completely remove both the cyanobacteria and the associ- 
ated MCs (MC-LR, MC-LY and MC-LF), regardless of the water recovery rate and the pre-treatment used. $\mathrm{RO}$ membranes are dense, nonporous and target low molecular weight molecules for removal. Neumann and Weckesser (1998) have studied the removal of two MC variants (LR and RR) in tap water. Removal was greater than $96 \%$ in all membranes tested for MC-LR and -RR, with both varieties being removed equally well. Vuori and associates (1997) found similar results for the removal of nodularin in brackish waters by $\mathrm{RO}$. $\mathrm{RO}$ and $\mathrm{NF}$ processes require a high level of maintenance to prevent membrane fouling by natural organic matter and cyanobacterial cells during cyanobacterial blooms (Miller, et al., 2001; Drikas, et al., 2001).

\section{Activated carbon}

Activated carbon is of interest in cyanotoxin removal due to the relatively small, hydrophobic nature of some of the organic toxin molecules. Consequently, activated carbon adsorption is listed as a process to remove cyanobacterial toxins by the WHO (2008).

The activated carbon approach uses either powdered activated carbon (PAC), which can be added occasionally when there is a need, or granular activated carbon adsorbers (GAC), which are used continuously (Newcombe, 2002).

PAC is effective as a pre-treatment chemical, for transient contaminants, prior to a conventional treatment plant. PAC was successfully used to treat high $\mathrm{MC}$ levels in a drinking water treatment process (Nasri, et al., 2007). For effective toxin removal very high doses of PAC are required, and very important parameter is contact time (Chorus, Bartram, 1999; Song, et al., 2005). Competition with natural organic matter reduces PAC adsorption capacity for MCs (Donati, et al., 1994; Svrcek, Smith, 2004).

GAC is used in fixed beds to reduce natural organic matter, taste and odor compounds, and synthetic organic compounds from industrialized source waters. GAC filtration has been shown to be effective in removing $\mathrm{MC}$ from water using both adsorption and biodegradation removal mechanisms (Wang, et al., 2007).

Although both powdered and granular activated carbon have proven effective, the presence in the water of other organic pollutants that could be adsorbed by the activated carbons needs to be considered. Due to frequent replacement or regeneration, the activated carbon adsorption method might become expensive (Lee, et al., 2005).

\section{Probiotic bacteria}

Specific strains of probiotic bacteria (Lactobacillus rhamnosus strains GG and LC-705, Bifidobacterium longum 46, Bifidobacterium lactis 420 and Bifidobacterium lactis $\mathrm{Bb} 12$ ) were shown to be the effective in cy- anobacterial toxin (MC-LR) removal from aqueous solutions. The highest removal percentage of MC-LR was $58.1 \%$, observed with B. lactis Bb12. Freshly cultured bacteria were shown to be more efficient in MC removal than lyophilized or nonviable bacteria. Removal of MC-LR was shown to be dependent on both temperature and bacterial concentration. Therefore, some of the tested strains have good potential in removing MCs from aqueous solutions (Nybom, et al., 2007).

\section{Oxidation}

Chemical removal processes for cyanotoxins mainly involve the use of oxidants to break down the organic molecules which cause toxicity. In addition to directly attacking the toxin molecule, oxidants may also cause damage to cyanobacterial cell membranes, which may result in cell lysis and subsequent toxin release. Primary oxidants in drinking water are potassium permanganate, chlorine, chlorine dioxide, chloramines, hydroxyl radical, and ozone. With respect to oxidation rates of oxidants, the general order of reaction rate from highest to lowest is hydroxyl radical $(\mathrm{OH})>$ ozone $\left(\mathrm{O}_{3}\right)>$ chlorine dioxide $\left(\mathrm{ClO}_{2}\right)>$ potassium permanganate $\left(\mathrm{KMnO}_{4}\right)>$ chlorine $\left(\mathrm{Cl}_{2}\right)>$ chloramines (Crittenden, et al., 2005). These oxidants are commonly used before chemical addition, before filtering, or after filtering as disinfectants (Westrick, et al., 2010).

Permanganate mainly reacts with double bonds by donating oxygen, but it can also abstract hydride ions, electrons, or hydrogen atoms. Compared to other oxidants, permanganate is sometimes preferred because of its relatively low cost, ease to handle, effective over a wide $\mathrm{pH}$ range, and stabile in the subsurface (Waldamer, Tratnyek, 2006). Oxidation of organic matter using permanganate does not lead to the formation of chlorinated or brominated byproducts (Rodriguez, et al., 2007a).

Chlorine reacts with activated aromatic systems and neutral amines, and chlorine dioxide reacts with tertiary amines and activated aromatic systems. Reports suggested that chlorination with $\mathrm{pH}<8.0$ is an effective mechanism for inactivation of MCs (Acero, et al., 2005; Ho, et al., 2006). An important point when considering chlorination as a water treatment is the possible exposure to toxic levels of chlorine in the air, the risk of lysing algal cells and formation of excess levels of trichalomethanes (Chorus, Bartram, 1999; Newcombe, 2002; Acero, et al., 2005; Rodriguez, et al., 2007b).

Ozone can be used as a primary disinfectant. Ozone gas is formed by passing dry air or oxygen through a high-voltage electric field. Effectiveness of ozonation varies depending upon the disinfectant dose and type of cyanotoxin. Byproduct formation is, also, a concern with ozonation. The toxicity of any ozonation/ cyanotoxin byproducts has been reported to decrease 
with increasing ozone dose (Brooke, et al., 2006; Rodriguez, et al., 2007c).

Results have shown that permanganate is a feasible option for the elimination of anatoxin and MCLR, while chlorine is a possible oxidant for the oxidation of cylindrospermopsin and MC-LR, and ozone can effectively oxidize all three toxins (Rodriguez, et al., 2007c).

\section{Advanced oxidation - Fenton process}

Fenton process has been studied for the degradation of MC-LR. Fenton reagent is a mixture of ferrous ions and hydrogen peroxide which produces extremely reactive hydroxyl radicals. Total degradation of MC-LR and MC-RR was achieved in only 60 seconds (Al Momani, 2007) with Fenton process. When this process was combined with a lower ozone dose, Al Momani and associates (2008) found that the common variants of MC (LR and RR) could be degraded quickly (8o seconds). Furthermore, the combination of ozone with hydrogen peroxide or ferrous led to the elimination of all the anatoxin-a below the detection limit in less than $180 \mathrm{sec}-$ onds (Al Momani, 2007). In the Photo-Fenton process, in which UV radiation was involved, the removal efficiency of MC-LR reached $84 \%$ in the first $25 \mathrm{~min}$ and $100 \%$ in approximately $35-40$ min of irradiation (Bandala, et al., 2004). Despite the high removal efficiency, Fenton process suffers from drawbacks that limit its applicability in municipal water treatment such as the creation of excess iron sludge (Svrcek, Smith, 2004).

\section{UV photolysis}

The absorption of UV energy can break molecular bonds without chemical addition and is used to inactivate many pathogens in drinking water. $\mathrm{MC}$, anatoxina, and cylindrospermopsin can undergo photolytic destruction at doses that range from 1,530 and $20,000 \mathrm{~mJ} /$ $\mathrm{cm}^{2}$, which are orders of magnitude higher than that needed for disinfection (10 and $40 \mathrm{~mJ} / \mathrm{cm}^{2}$ ) (Tsuji, et al., 1994; Chorus, Bartram, 1999; Senogles, et al., 2000). Low pressure narrow-band mercury vapor lamps at $254 \mathrm{~nm}$ degraded cylindrospermopsin above $643 \mathrm{~mJ} / \mathrm{cm}^{2}(\mathrm{Ho}$, et al., 2009). Low to medium pressure lamp UV treatment is not recommended as a viable treatment barrier for cyanotoxins. High doses of UV radiation (1,530$20,000 \mathrm{~mJ} / \mathrm{cm}^{2}$ ) for the successful photolysis of MCs are required, which is impractical for full-scale water treatment (Drikas, et al., 2001; Svrcek, Smith, 2004).

\section{Conclusion}

To preserve healthy and sustainable environment with valuable water resources, it is necessary to change our behavior and past practices. In order to restore water quality, various techniques and methods in water treatment procedures must be employed. These procedures include technologies like coagulation/floculation, flotation, filtration, activated carbon adsorption, UV photolysis, ozonization and oxidation processes. They are used for elimination of cyanobacterial cells and toxins which represent same of the problems that affect water quality.

In Serbia there is a problem with cyanobacterial blooms and production of cyanotoxins in most of the surface freshwaters which are used as a water supply reservoirs, for recreation and irrigation. Also, very small number of waterworks in Serbia control cyanobacterial growth, measure concentration of cyanotoxins in surface freshwaters and use water treatment for toxin removal. This practice should be changed to improve general water quality status in Serbia with methods for elimination of cells and toxic substances produced by cyanobacteria, in order to re-establish natural balance in water ecosystems and drinking water reservoirs.

\section{Acknowledgements}

The authors would like to acknowledge the funding of the Ministry of Science and Environmental protection of the Serbian government (project number 176020).

\section{References}

Acero, J.L., Rodriguez, E., Meriluoto, J. 2005. Kinetics of reactions between chlorine and the cyanobacterial toxins microcystins. Water Res 39, 8, 1628-1638.

Al Momani, F. 2007. Degradation of Cyanobacteria Anatoxin-a by Advanced Oxidation Processes. Separation and Purification Technology 57, 1, 85-93.

Al Momani, F., Smith, D.W., Gamal El-Din, M. 2008. Degradation of cyanobacteria toxin by advanced oxidation processes. J Hazard Mater 150, 2, 238-249.

Babica, P., Blaha, L., Maršalek, B. 2006. Exploring the natural role of microcystins - a review of effects on photoautotrophic organisms. Journal of Phycology 42, 1, 9-20.

Bandala, E.R., Martinez, D., Martinez, E., Dionysiou, D.D. 2004. Degradation of microcystin-LR toxin by Fenton and Photo-Fenton processes. Toxicon 43, 7, 829-832.

Bourne D.G., Blakeley R.L., Riddles P., Jones G.J. 2006. Biodegradation of the cyanobacterial toxin microcystin-LR in natural water and biologically active slow sand filters. Water Res 40, 6, 1294-1302.

Briand, J-F., Jacquet, S., Bernard, C., Humbert, J-F. 2003. Health hazards for terrestrial vertebrates from toxic cyanobacteria in surface water ecosystems. Vet Res 34, 4, 361-377.

Brooke, S., Newcombe, G., Nicholson, B., Klass, G. 2006. Decrease in toxicity of microcystins-LA and 
LR in drinking water by ozonation. Toxicon 48,8 , 1054-1059.

Chorus, I. (eds.) 2001. Cyanotoxins - occurrence, causes, consequences. Springer-Verlag, Heidelberg. Germany.

Chorus, I., Bartram, J.F. (eds.) 1999. Toxic cyanobacteria in water: A guide to their public health consequences, monitoring and management. E \& FN Spon. WHO. London.

Crittenden, J.C., Trussell, R.R., Hand, D.W., Howe, K.J., Tchobanoglous, G. 2005. Water treatment: Principles and design. 2nd ed. John Wiley \& Sons. Inc. Hoboken. New Jersey.

Dietrich, D., Hoeger, S. 2005. Guidance values for microcystins in water and cyanobacterial supplement products (blue-green algal supplements): a reasonable or misguided approach? Toxicol Appl Pharmacol 203, 3, 273-89.

Donati, C.D., Drikas, M., Hayes, R., Newcombe, G. 1994. Microcystin-LR adsorption by powdered activated carbon. Wat Res 28, 8, 1735-1742.

Drikas, M., Chow, C.W.K., House, J., Burch, M.D. 2001. Using coagulation, flocculation, and settling to remove toxic cyanobacteria. J Am Water Works Assoc 93, 2, 100-111.

Drobac, D., Svirčev, Z., Tokodi, N., Vidović, M., Baltić, V., Božić-Krstić, V., Lazić, D., Pavlica, T. 2011. Microcystins - potential risk factors in carcinogenesis of primary liver cancer in Serbia. Geographica Pannonica $15,3,70-80$.

Falconer, I.R. 2005. Is there a human health hazard from microcystins in the drinking water supply? Acta Hydrochim Hydrobiol 33, 1, 64-71.

Falconer, I.R. 2008. Health effects associated with controlled exposures to cyanobacterial toxins. Adv Exp Med Biol 619, 607-12.

Gijsbertsen-Abrahamse, A.J., Schmidt, W., Chorus, I., Heijman, S.G.J. 2006. Removal of cyanotoxins by ultrafiltration and nanofiltration. J Membr Sci 276, 1-2, 252-259.

Griffiths, D.J., Saker, M.L. 2003. The Palm Island mystery disease 20 years on: A review of research on the cyanotoxin cylindrospermopsin. Environ Toxicol 18, 2, 78-93.

Grutzmacher, G., Bottcher, G., Chorus, I., Bartel, H. 2002. Removal of microcystins by slow sand filtration. Environ Toxicol 17, 4, 386-394.

Hitzfeld, B., Hoger, S., Dietrich, D. 200o. Cyanobacterial toxins: Removal during drinking water treatment, and human risk assessment. Environ Health Perspect 108, suppl 1, 113-122.

Ho, L., Onstad, G., v Gunten, U., Rinck-Pfeiffer, S., Craig, K., Newcombe, G. 2006. Differences in the chlorine reactivity of four microcystin analogues. Water Res 40, 6, 1200-1209.
Ho, L., Tanis-Plant, P., Kayal, N., Slyman, N., Newcombe, G. 2009. Optimising water treatment practices for the removal of Anabaena circinalis and its associated metabolites, geosmin and saxitoxins. J Water Health 7, 4, 544-556.

Hoeger, S.J., Shaw, G., Hitzfeld, B.C., Dietrich, D.R. 2004. Occurrence and elimination of cyanobacterial toxins in two Australian drinking water treatment plants. Toxicon 43, 6, 639-49.

Hrudey, S.E., Burch, M., Drikas, M., Gregory, R. 1999. Remedial measures. In: Chorus, I., Bartram, J. (eds.). Toxic cyanobacteria in water: A guide to their public health consequences, monitoring and management. E \& FN Spon. WHO. London.

Hudnell, H.K. 2010a. The state of U.S. freshwater harmful algal blooms assessments, policy and legislation. Toxicon 55, 5, 1024-1034.

Hudnell, H.K. 2010b. Within water-body management: a needed but neglected complement to watershed management. Clean Technol Environ Policy $12,3,205-207$.

Ibelings, B.W., Havens, K.E. 2008. Cyanobacterial toxins: a qualitative meta-analysis of concentrations, dosage and effects in freshwater, estuarine and marine biota. Adv Exp Med Biol 619, 675-732.

IARC, 2006. Ingested nitrate and nitrite, and cyanobacterial peptide toxins. IARC monographs on the evaluation of carcinogenic risks to humans. Vol. 94. WHO. International Agency for Research on Cancer. Lyon. France.

Juković, M., Svirčev, Z., Baltić, V., Stojanović, D., Mihajlović, A., Baltić, M. 2008. Cyanotoxins - new health risk factor in Serbia. Arch Oncol 16, 3-4, 558.

Kaebernick, M., Neilan B.A. 2001. Ecological and molecular investigations of cyanotoxin production. FEMS Microbiology Ecology 35, 1, 1-9.

Lahti, K., Rapala, J., Kivimaki, A.-L., Kukkonen, J., Niemela, M., Sivonen, K. 2001. Occurrence of microcystins in raw water sources and treated drinking water of Finnish waterworks. Water Science and Technology 43, 12, 225-228.

Lee, J-W., Choi, D-Y., Kwak, D-H., Jung, H-J., Shim, W-S., Moon, H. 2005. Adsorption dynamics of water vapor on activated carbon. Adsorption 11, suppl 1, 437-441.

Lee, J-W., Walker, H. 2006. Effect of process variables and natural organic matter on removal of microcystin-LR by PAC-UF. Environ Sci Technol 40, 23, 7336-7342.

Lepisto, L., Lakti, K., Niemi, J. 1994. Removal of cyanobacteria and other phytoplankton in four finish waterworks. Algolog Stud 75, 167-181.

Miller, M.J., Critchley, M.M., Hutson, J. Fallowfield, H.J. 2001. The adsorption of cyanobacterial hepa- 
totoxins from water onto soil during batch experiments. Water Res 35, 6, 1461-1468.

Mouchet, P., Bonnelye, V. 1998. Solving algae problems: French expertise and world-wide applications. Aqua 47, 3, 125-141.

Nasri, H., Bouaicha, N., Kaid Harche, M. 2007. A new morphospecies of Microcystis sp. forming bloom in the Cheffia dam (Algeria): Seasonal variation of microcystin concentrations in raw water and their removal in a full-scale treatment plant. Environ Tox 22, 4, 347-356.

Neumann, U., Weckesser, J. 1998. Elimination of microcystin peptide toxins from water by reverse osmosis. Environ Toxicol Water Qual 13, 2, 143-148.

Newcombe, G. 2002. Removal of algal toxins from drinking water using ozone and GAC. AWWA Research Foundation and AWWA. Denver.

Nybom, S., Salminen, S., Meriluoto, J. 2007. Removal of microcystin-LR by strains of metabolically active probiotic bacteria. FEMS Microbiol Lett 270, 1, 27-33.

Pietsch, J., Bornmann, K., Schmidt, W. 2002. Relevance of intra- and extracellular cyanotoxins for drinking water treatment. Acta Hydrochim Hydrobiol 30, 1, 7-15.

Ribau Teixeira, M., Rosa, M.J. 2006a. Comparing dissolved air flotation and conventional sedimentation to remove cyanobacterial cells of Microcystis aeruginosa: Part I: The key operating conditions. Separation and Purification Technology 52, 1, 84-94.

Ribau Teixeira, M., Rosa, M.J. 2006b. Neurotoxic and hepatotoxic cyanotoxins removal by nanofiltration. Water Res 40, 15, 2837-2846.

Rodriguez, E., Majado, M.E., Meriluoto, J., Acero, J.L. 2007a. Oxidation of microcystins by permanganate: reaction kinetics and implications for water treatment. Water Res 41, 1, 102-110.

Rodriguez, E., Sordo, A., Metcalf, J.S., Acero, J.L. 2007 b. Kinetics of the oxidation of cylindrospermopsin and anatoxin-a with chlorine, monochloramine and permanganate. Water Res 41, 9, 20482056.

Rodriguez, E., Onstad, G.D., Kull, T., Metcalf, J.S., Acero, J.L., von Gunten, U. 2007c. Oxidative elimination of cyanotoxins: Comparison of ozone, chlorine, chlorine dioxide and permanganate. Water Res 41, 15, 3381-3393.

Senogles, P., Shaw, G., Smith, M., Norris, R., Chiswell, R., Mueller, J., Sadler, R., Eaglesham, G. 200o. Degradation of the cyanobacterial toxin cylindrospermopsin, from Cylindrospermopsis raciborskii, by chlorination. Toxicon 38, 9, 1203-1213.

Simeunović, J., Svirčev, Z., Krstić, S., Lazić, L. 2005. Occurence of cyanobacterial blooms in Vojvodina water ecosystems. Geographica Pannonica 9, 13-19.
Song, W., Teshiba, T., Rein, K., O’Shea, K.E. 2005. U1trasonically induced degradation and detoxification of microcystin-LR (cyanobacterial toxin). Environ Sci Technol 39, 16, 6300-6305.

Svirčev, Z., Mikov-Miladinov, M., Simeunović, J., Vidović, M., Matavulj, M., Petrović, D., Radojčić, B., Stojanović, D. 2006. PLC epidemiological studies in Central Serbia potentially connected with cyanobacterial blooms in drinking water suppliers. Proc. Int. Conf. "Danubius Pannonico Mysicus Space of Challenges" Novi Sad.

Svirčev, Z., Simeunović, J., Subakov-Simić, G., Krstić, S., Vidović, M. 2007. Freshwater cyanobacterial blooms and cyanotoxin production in Serbia in the past 25 years. Geographica Pannonica 11, 12-21.

Svirčev, Z., Krstić, S., Marković, S.B., Plavša, J., Lazić, L. 2008. Methods for management of eutrophication in freshwater ecosystems in Vojvodina. Geographica Pannonica 12, 1, 4-11.

Svirčev, Z., Krstić, S., Miladinov-Mikov, M., Baltić, V., Vidović. M. 2009. Freshwater cyanobacterial blooms and primary liver cancer epidemiological studies in Serbia. J Environ Sci Health C Environ Carcinog Ecotoxicol Rev 27, 1, 36-55.

Svrcek, C., Smith, D.W. 2004. Cyanobacteria toxins and the current state of knowledge on water treatment options: a review. J Environ Eng Sci 3, 155-185.

Tsuji, K., Naito, S., Kondo, F., Ishikawa, N., Watanabe, M.F., Suzuki, M., Harada, K.I. 1994. Stability of microcystins from cyanobacteria: II Effect of light on decomposition and isomerization. Environ Sci Technol 28, 173-177.

Vuori, E., Pelander, A., Himberg, K., Waris, M. 1997. Removal of nodularin from brackish water with reverse osmosis or vacuum distillation. Water Res 31, 11, 2922-2924.

Waldemer, R.H., Tratnyek, P.G. 2006. Kinetics of contaminant degradation by permanganate. Environ Sci Technol 40, 3, 1055-1061.

Wang, L.K., Fahey, E.M., Wu, Z. 2005. Dissolved air flotation. In: Wang, L.K., Hung, Y.T., Shammas, N.K. (eds.). Physicochemical treatment processes. Volume 3. Handbook of Environmental Engineering. Humana Press. Totowa. NJ.

Wang, H., Ho, L., Lewis, D.M., Brookes, J.D., Newcombe, G. 2007. Discriminating and assessing adsorption and biodegradation removal mechanisms during granular activated carbon filtration of microcystin toxins. Water Res 41, 18, 4262-4270.

Westrick, J., Szlag, D., Southwell, B., Sinclair, J. 2010. A review of cyanobacteria and cyanotoxins removal/ inactivation in drinking water treatment. Anal Bioanal Chem 397, 5, 1705-1714.

WHO, 1998. Guidelines for drinking water quality. Addendum to Vol.2. Cyanobacterial toxins: Micro- 
cystin-LR. Geneva. Switzerland. World Health Organization.

WHO, 2003. Algae and cyanobacteria in freshwater. In: Guidelines for Safe Recreational Water Environments, vol. 1: Coastal and Fresh Waters. Geneva, Switzerland, pp. 136-158.

WHO, 2004. Guidelines for drinking water quality. Vol.1. $3^{\text {rd }}$ edition. Geneva. Switzerland. World Health Organization.

WHO, 2008. Guidelines for drinking-water quality: incorporating $1^{\text {st }}$ and $2^{\text {nd }}$ addenda. Vol.1. $3^{\text {rd }}$ edition. Geneva. Switzerland. World Health Organization.
Yoo, S.R., Carmichael, W.W., Hoehn, R.C., Hrudey, S.E. 1995. Cyanobacterial blue-green algal toxins: A resource guide. AWWA Research Foundation and AWWA. Denver.

Zhang, C., Fu, D., Gu, Z. 2009. Degradation of microcystin-RR using boron-doped diamond electrode. $J$ Hazard Mater 172, 2-3, 847-853.

Žegura, B., Sedmak, B., Filipič, M. 2003. Microcystin-LR induces oxidative DNA damage in human hepatoma cell line HepG2. Toxicon 41, 1, 41-48. 